\title{
НАЙБІЛЬШ ПОШИРЕНІ ТОКСИЧНІ СИНДРОМИ, ЩО ВИНИКАЮТЬ ПРИ ОТРУЄННІ ДИКОРОСЛИМИ ОТРУЙНИМИ ТА УМОВНО ЇСТІВНИМИ ГРИБАМИ
}

\author{
Б. А. Локай, С. В. Циганкова \\ ДвНз «Тернопільський державний медичний університет \\ імені І. Я. Горбачевського МОз Украӥни» \\ Комунальна установа «Міська клінічна лікарня екстреної \\ та швидкої медичної допомоги м. Запоріжжя"
}

У статті розглянуто питання епідеміології, клініки та основних принципів лікування гострих отруєнь дикорослими грибами. Наведено дані щодо захворюваності гострими отруєннями дикорослими грибами серед пацієнтів, які перебували на лікуванні у відділенні інтенсивної терапії Комунальної установи «Міська клінічна лікарня екстреної та швидкої медичної допомоги м. Запоріжжя».

\section{THE MOST COMMON TOXIC SYNDROMES RELATED TO WILD MUSHROOM POISONINGS}

\author{
B. A. Lokay, S. V. Tsyhankova \\ I. Horbachevsky Ternopil State Medical University \\ Municipal Institution "City Emergency and Ambulance Hospital, Zaporizhzhia»
}

\begin{abstract}
The article provides a review of epidemiology, clinical manifestations and main treatment principles of wild mushroom poisonings. The data regarding morbidity and mortality related to these poisonings among the patients, treated in the intensive care department of the Municipal institution «City Emergency and Ambulance Hospital, Zaporizhzhia» are presented in the article.
\end{abstract}

Вступ. За останні роки в Україні, як і в більшості розвинутих країн, спостерігається зростання захворюваності на гострі отруєння. За даними Всесвітньої федерації токсикологічних центрів у світі відбувається формування токсичної ситуації, що пов'язана зі зростанням кількості отруєнь. Близько 5 \% від числа всіх звернень за невідкладною медичною допомогою у дорослих пов'язані з гострими отруєннями і від 2-5 \% із отруєннями в дітей [1].

Увага медиків до отруєнь грибами викликана тяжким перебігом захворювання, високими показниками стаціонарної летальності, надзвичайно високою вартістю та складністю лікування. Зазначені фактори висувають проблему отруєнь дикорослими грибами на одне з перших місць у структурі отруєнь харчовими токсикантами.

Згідно з інформацією Державного закладу «Український центр з контролю та моніторингу захворювань Міністерства охорони здоров'я України» в 2016 р. (9 міс.) вже зареєстровано 228 випадків отруєнь ди-

\footnotetext{
(с) Б. А. Локай, С. В. Циганкова, 2016
}

корослими отруйними та умовно їстівними грибами. Але смертність при цьому менша, ніж у минулі роки (13 випадків у 2016 р. проти 17 в 2015 р.). Також у поточному році зросла кількість випадків отруєння грибами серед дітей (40 випадків у 2016 р. проти 23 в 2015 р.). Найбільше людей, які отруїлись грибами, в 2015 р. реєстрували у Дніпропетровській (29 проти 1 випадку в 2014 р.) та Закарпатській (23 проти 25 у 2014 р.) областях.

Метою даного дослідження був обраний аналіз найбільш поширених токсичних синдромів і невідкладних станів, що виникають при отруєнні дикорослими отруйними та умовно їстівними грибами, поширеними в Запорізькому регіоні.

Проведений ретроспективний аналіз результатів клініко-лабораторного обстеження та лікування пацієнтів із діагнозом «отруєння грибами».

Основна частина. Досліджено випадки гострих отруєнь дикорослими отруйними та умовно їстівними грибами серед дорослого населення м. Запоріжжя та області за 2011-2016 рр. (усього 20 випадків). Усі 
пацієнти проходили стаціонарне лікування на базі відділення інтенсивної терапії загального профілю КУ «Міська клінічна лікарня екстреної та швидкої медичної допомоги м. Запоріжжя».

Причини, що зумовили велику кількість госпіталізованих із діагнозом «отруєння грибами» у Запоріжжі та Запорізькій області в період з 2011 до 2016 р., пов'язані з низкою факторів:

- необізнаністю переважної частки населення про можливі фатальні наслідки, до яких призводить споживання нерозпізнаних отруйних грибів;

- втратою населенням навичок розпізнавання їстівних грибів (серед осіб, госпіталізованих із отруєнням грибами, значно переважає міське населення);

- легковажним та недовірливим ставленням певної частки населення до застережень місцевих органів охорони здоров'я проти збирання грибів через засоби масової інформації;

- потраплянням до грибного кошика молодих екземплярів отруйних грибів, яких навіть грибники з досвідом іноді плутають із печерицями та деякими іншими їстівними грибами;

- введенням у їжу грибної суміші, коли збираються декілька різновидів грибів, серед яких трапляються й отруйні екземпляри;

- неправильною або неповною кулінарною обробкою грибів;

- погіршенням соціально-економічної ситуації на місцях, що спонукає населення розширювати свій харчовий раціон за рахунок дикорослих грибів, що поставило проблему отруєнь грибами на одне з перших місць у структурі отруєнь харчовими токсикантами;

- споживання отруйних грибів зі суїцидальною метою;

- споживання отруйних грибів на тлі психічних захворювань, коли людина не усвідомлює можливі негативні наслідки.

Переважна більшість пацієнтів з отруєнням грибами - це люди зрілого віку. Це пов'язано, скоріше за все, з погіршенням соціально-економічної ситуації у містах, що спонукає населення розширювати свій харчовий раціон за рахунок дикорослих грибів.

Залежно від виду спожитих грибів, наявності в них певних токсинів, часу, що минув від споживання грибів до перших клінічних проявів, маніфестації типових синдромів загальноприйнятною $є$ посиндромна класифікація грибних отруєнь [2-4], яка передбачає їх розподіл на 3 групи:

І. Отруєння грибами з гастроентеротропною дією.
II. Отруєння грибами з нейротропною дією.

III. Отруєння грибами з гепатонефротропною дією.

Отруєння грибами I групи зумовлено введенням у їжу грибів різних видів (рядовка отруйна, опеньок несправжній сірчано-жовтий, опеньок несправжній цегляно-червоний, печериця отруйна, печериця темнолоскутна, ентолома отруйна, ентолома сіра отруйна), спільною для яких $\epsilon$ наявність у грибах подразнюючих речовин та біогенних амінів, які, як правило, не мають резорбтивної дії. Клінічна картина при отруєнні ними доволі характерна: швидкий початок захворювання (через 20 хвилин, рідше - через 2-3 години після споживання), клініка гастроентериту, що продовжується, як правило, від декількох годин до доби. За відсутності супутніх суб-та декомпенсованих захворювань від отруєнь грибами цієї групи хворі не помирають. Прогноз сприятливий. Лікування симптоматичне, в основному направлено на відновлення водно-електролітних втрат, деконтамінацію отрути, що не всмокталася (активоване вугілля внутрішньо, сорбіт при відсутності проносу). Антидотних засобів не існує.

До отруєнь грибами // групи найчастіше призводить споживання досить небезпечних Inocybe patujara, Amanita muscaria, Amanita panterina, Clitocybe dealbata, Clitocybe cerusata, Omphalotus olearius та деяких інших. Перші клінічні прояви - у період від 30 хвилин до 2 годин після споживання грибів. Залежно від виду грибів у них містяться речовини, що зумовлюють клінічну картину отруєння (мускарин, мускаридин). При переважанні вмісту мускарину (при отруєнні грибами Inocybe Patujara, Amanita muscaria, Amanita panterina) у клінічній картині превалює холінергічний синдром: міоз, слиновиділення, бронхорея, бронхоконстрикція, нападоподібний різкий біль уживоті, нудота, блювання, пронос. Домішки мускаридину та речовин із подібною йому дією проявляються у цих хворих мідріазом, сльозотечею, пітливістю, згодом приєднується ураження центральної нервової системи: сплутана свідомість, марення, загальмованість, дезорієнтація, що пізніше змінюється сопорозним станом [5].

При отруєнні грибами, в яких переважає мускаридин (гриби Clitocybe dealbata, Clitocybe cerusata, Omphalotus olearius) та його похідні - іботенова кислота, мусцимол, на перший план виступає антихолінергічний синдром, що проявляється насамперед порушенням свідомості: поведінковими порушеннями, психомоторним збудженням, маренням, галюцинаціями, мідріазом, пітливістю, судомами, сповільненням 
перистальтики аж до розвитку динамічної кишкової непрохідності.

Лікування спрямоване на відновлення вітальних функцій, видалення отрути з шлунково-кишкового тракту (промивання шлунка, активоване вугілля у комбінації з проносними засобами). При переважанні симптоматики інтоксикації мускарином внутрішньовенно вводять атропін до отримання клінічних ознак помірної атропінізації. При переважанні симптоматики інтоксикації мускаридином як антидотні засоби призначають внутрішньовенно фізостигмін або аміностигмін чи галантамін. Проводять інфузійну терапію. Прогноз за умови адекватного лікування сприятливий.

До отруєнь грибами III групи належать найбільш небезпечні для життя отруєння, які зумовлюють до 60 \% летальності при отруєнні блідою поганкою у хворих на стадії токсичного гастроентероколіту, які не зверталися за медичною допомогою (2-3 доба хвороби) та 10-15 \% - у спеціалізованих відділеннях інтенсивної терапії.

Клінічна картина характеризується фазністю розвитку патологічних симптомів. На основі вивчених ознак отруєння блідою поганкою, що з'являються в відносно чіткій хронологічній послідовності, виділені такі 5 періодів розвитку захворювання:

I - латентний період;

II - період гострого гастроентериту;

III - період уявного благополуччя;

IV - період гострої печінкової, печінково-ниркової недостатності;

$$
\text { V - період одужання. }
$$

Тривалість латентного періоду становить 6-9 год, в окремих випадках 10-15 год і вкрай рідко 16-36 год. Час до появи перших симптомів отруєння зумовлений не тільки кількістю токсичної речовини, що потрапила в організм, а й її концентрацією в одночасно спожитій харчовій масі, а також складовими компонентами.

Латентний період завершується неспецифічними, загальноклінічними проявами - загальною слабістю, нездужанням, розбитістю, що розцінюється як провісник подальшого розвитку клінічної картини отруєння. В період гострого гастроентериту в клінічній картині отруєння переважають симптоми ураження шлунково-кишкового тракту.

Зневоднення, порушення водно-електролітного балансу і КОС, а також наростаюча ендотоксемія зумовлюють розвиток гемодинамічних розладів: гіпотонії і тахікардії. У разі тяжкого отруєння блідою поганкою ураження шлунково-кишкового тракту призводить до глибоких розладів гомеостазу та небезпечних для життя порушень серцево-судинної діяльності. Ці ускладнення тяжче переносять діти і люди похилого віку, компенсаторні можливості організму яких значною мірою обмежені.

Тривалість періоду становить 2-6 діб. У міру стихання гострого гастроентериту настає період уявного благополуччя, пов'язаний з припиненням болісних відчуттів у животі, тенезмів, нудоти і блювоти. Самопочуття хворих поліпшується. Поліпшення стану часом розцінюється як тенденція до одужання, але через деякий час (від декількох годин до 1-2 днів) стан знову погіршується, що пов'язано з наростанням вісцерального ураження. Варто зазначити, що у тяжких випадках отруєння поліпшення стану не відбувається і захворювання безпосередньо переходить в наступну стадію - гострої печінкової, печінково-ниркової недостатності [6].

Летальність при отруєнні блідою поганкою коливається від 20-90 \% і є найвищою серед усіх отруєнь отруйними грибами і рослинами.

Лікування передбачає відновлення вітальних функцій, елімінацію отрути з шлунково-кишкового тракту (промивання шлунка, активоване вугілля у комбінації з проносними засобами), інфузійну терапію, антидотну терапію (бензилпеніцилін, силібінін), прискорення виведення аманітальних токсинів з організму хворого (ранній плазмаферез, гемофільтрація, гемосорбція/ гемокарбоперфузія, примусовий діурез), гепатопротекторну терапію, симптоматичну терапію (лікування порушень коагуляції, метаболічних, циркуляторнихта дихальних ускладнень).

За період спостереження отруєння грибами гепатонефротропної дії становили 30 \% (6 випадків), отруєння грибами гастроентеротропної дії - 60 \% (12 випадків), з нейротропною дією - 10 \% (2 випадки).

3 огляду на те, що в Україні не проводиться лабораторна ідентифікація грибних токсинів через високу вартість досліджень, відсутність обладнання, складність мікологічної ідентифікації, діагноз «отруєння грибами» (MKX-10: Т62.0) повинен базуватися на токсикологічному й епідеміологічному анамнезі, клінічних проявах, клініко-біохімічних даних і результатах допоміжних методів дослідження. У складних для діагностики випадках необхідно залучати суміжних спеціалістів (неврологів, гастроентерологів, хірургів, інфекціоністів).

Висновки. 1. Отруєння грибами є актуальною проблемою в багатьох країнах. При отруєнні грибами 
гостра печінкова, ниркова та кишкова недостатність $\epsilon$ результатом диференційованого впливу грибного токсину на внутрішні органи. Токсичний ефект у цих випадках проявляється розвитком специфічної гепатонефроентеропатії.

2. У першу добу нерідко складно визначити вид грибного отруєння. Велику роль відіграє диференційна діагностика.

3. Як показують дані, які були отримані в ході ретроспективного аналізу результатів клініко-лабораторного обстеження та лікування пацієнтів у відділенні

\section{ЛІТЕРАТУРА}

1. Наукове обґрунтування організації медичної допомоги населенню України при гострих отруєннях : звіт про науково-дослідну роботу / Б. С. Шейман, С. П. Борщов, С. М. Недашківський [та ін.]. - 2008. - 334 с.

2. Kaufmann P. Mushroom poisonings: syndromic diagnosis and treatment / P. Kaufmann // WienMed. Wochenschr. - 2007. - № 157(19-20). - P. 493-502.

3. Элленхорн М. Дж. Медицинская токсикология: диагностика и лечение отравлений у человека : в 2 томах / М. Дж. Элленхорн. - М. : Медицина, 2003. - С. 962-977. інтенсивної терапії загального профілю КУ «Міська клінічна лікарня екстреної та швидкої медичної допомоги м. Запоріжжя» за період 2011-2016 рр., у більшості пацієнтів (60 \%) відмічали отруєння грибами з гастроентеротропною дією, далі (30 \%) - пацієнти з отруєнням грибами з гепатонефротропною дією i найменшу частку (10 \%) склали пацієнти з отруєнням грибами з нейротропною дією.

4. Отримані результати дослідження загалом відповідають даним, які наведено в літературі та інших наукових дослідженнях.

4. Недашківський С. М. Отруєння грибами: діагностика, патофізіологія, клінічні прояви та невідкладна допомога. Сучасні підходи / С. М. Недашківський // Медицина невідкладних станів. - 2014. - № 2 (57). - С. 95-101.

5. Молдаван М. Г. Общетоксическое и нейротропное действие базидиальных грибов родов Amanita и Psilocybe / М. Г. Молдаван, А. А. Гродзинская // Современные проблемы токсикологии. - 2002. - № 2. - С. 15-21.

6. Медицинская токсикология: национальное руководство / под ред. Е. А. Лужникова. - М. : ГЭОТАР-Медиа, 2012. - С. 736-742. 